\title{
Classroom Communication in Early Childhood Education
}

\author{
Sarasvati Gita Swari ${ }^{*}$, Dewa Komang Tantra ${ }^{2}$, Ni Putu Astiti Pratiwi ${ }^{3}$
}

${ }^{123}$ English Language Education Study Program, Ganesha University of Education Singaraja, SIngaraja, Indonesia

A R T I C L E I N F O

Article history:

Received 19 July 2020

Received in revised

Form 09 September 2020

Accepted 20 October 2020

Available online 01

November 2020

Keywords:

Classroom

Communication, Early

Childhood Education.

\section{A B S T R A C T}

This study aims to investigated the speech act types and communication strategies in early childhood education. This research was a classroom research. Data were collected through unobtrusive observation during learning interactions. The obtained data were analyzed qualitatively. The recorded children's and teachers' speech acts were totaled 360. The research findings are as follows. Firstly, the recorded speech consisted of four types, they are: directive, expressive, declarative, and assertive acts. Directive acts were the most frequently used (93.3\%), followed by expressive acts $(5 \%)$, assertive acts $(1.4 \%)$, and declarative acts $(0.3 \%)$. The telling speech acts dominated the verbal interactions (44.4\%) followed by request speech acts $(32.2 \%)$. Secondly, 360 communication strategies were found. The telling and request sub-speech acts were delivered using compensatory strategies $(96.11 \%)$. The teachers used 280 code-switching strategies $(77.78 \%)$ while the children used none $(0 \%)$; 14 non-linguistic forms strategies $(3.89 \%)$ were used by the teachers while 6 self-repairs strategies (1.67\%) by the children; 14 all-purpose words strategies (3.89\%) were used by the teachers while none (0\%) by the children; 14 asking for repetitions strategies (3.89\%) were used by the teachers while none $(0 \%)$ by the children; none filters/hesitation devices strategy (0\%) was used by the teachers while $8(2.22 \%)$ by the children; none (0\%) literal translation strategy was used by the teachers while $12(3.33 \%)$ by the children. The most frequently directive acts imply towards the effectiveness of the children's communicative skill.

\section{Introduction}

Learning to communicate is the key for children to interact with others. In early childhood education (henceforth: ECE), communication is important to help children build academic skills and feel confidence in learning. Effective communication should take place with shared meaning and understanding between teachers and children in early childhood settings (Velentzas \& Broni,2014; Nurani,2017). Children learn to express thought, feeling, and information through communication (Gooden \& Kearns, 2013). One type of communication often used in ECE classroom interactions is verbal oral-face-to-face formal or informal communication (Bubikova-Moan, 2019). Oral communication may include speech acts. An effective communication strategy builds and maintains connections, allowing interactions to work efficiently toward the learning goals.

Bubikova-Moan studied play-based learning (PBL) in ECE. It was a qualitative meta-synthesis research of 62 studies from 24 national contexts. It was concluded that the previous researchers had differing views on the degree of compatibility between play and learning (Bubikova-Moan, 2019). The study was not focused particularly on communication forms and strategies. However, the study was in favor to a play strategy in a face-to-face interaction for children's holistic development as well as specific developmental areas such as social, emotional, cognitive and linguistic (Hunter and Walsh, 2014).

Few researches conducted on the effectiveness of speech acts and communication strategies in early childhood education. However, (Ryckebusch \& Marcos, 2004) conducted a study on pragmatic development in terms of speech acts in young children. Different speech act types were used in children's conversational with partners as long when they played. The three groups of ten French urban middleclass children became the participants of the study. They were observed in 8 and 12 minutes they played and interacted with their parents. The results showed parent's gender had a significant effect on the production of directive acts and assertive acts, while the play type had an impact on the production of requests and expressive acts.

Palupi conducted a study on identifying the use of communication strategies by sixth grade students of Cita Hati Elementary School in Surabaya. Student and teacher interaction during the EFL were 
observed to collect the data needed. The result showed that certain communication strategies were used such as gestures and avoidance (Palupi, 2008). Besides, (Syahrial, 2013) also conducted a study on the use of communication strategies. It was a qualitative descriptive study that investigated the communication strategies used by four third grade students of Bethany School. The video interactions that had been recorded were identified using observational indicator (Dornyei, 1995; Tarone, 1977; Zhang, 2007; Nimer, 2012). The results showed that seven compensatory strategies were used in their interaction to compensate their inadequacy in English.

The Elementary Schools' teachers and students became the participants of the study. The data were collected through observation, interviews, and note takings. This study found that teachers mostly produced directive acts rather than the students did, while the students were mostly produced assertive acts (Merdana, et al., 2013). The teachers' directive acts functioned as questions, bald imperatives, embedded imperatives, need statements, hint directives, and permission directives. The instructional functions of the teachers' speech acts were to control the children's behaviors, to organize learning situations, and to motivate children for learning. Besides, (Martínez-Adrián et al.,2017) conducted a study on self-reported use of communication strategies by content and language integrated learning (CLIL) in primary education. Learners' self-reported opinions about the use of communication strategies (guessing, miming, morphological creativity, dictionary, predicting, paraphrasing, borrowing, calque, foreignizing, avoidance and appeal for assistance) were being examined to collect the data needed. An adapted survey was administered to CLIL learners (Bongaerts \& Poulisse, 1987; Oxford, 1989; O'Malley \& Chamot, 1990; Yule \& Tarone, 1990). The results showed similar inclination in the overall frequency use of communication strategies. The sixth graders classified higher than the fifth graders in the use of borrowing and guessing. In contrast, foreignizing classified lower in the grade sixth. It showed noticeable similarities between both grades as well as differences in the use of communication strategies, paraphrasing and appeal for assistance being the most frequent strategies, while morphological creativity and miming being the lowest frequent strategies.

Previous conducted by (Oktaviani \& Misgiyati, 2018) find out communication strategies used by the Primary teachers at Palm Kids Elementary School of Lubuklinggau. The participants of the study were taken through purposive sampling. They were 3 teachers in grade 2, 5 and 6. The study was a descriptive qualitative research which the data was collected by using observation, interview, and documentation. The result showed that communication strategies used by the English teachers were code switching, intralingua, IL based strategies, non-linguistics, cooperative, and formal reduction. education.

This study aims to investigated the speech act types and communication strategies in childhood

\section{Methods}

The current research was to investigate the speech act types and communication strategies in early childhood's classroom interactions. The general research objective was geared to analyze the speech act types, their sub-types, and the communication strategies used by the teachers and children in early childhood education at Aura Sukma Insani Bilingual Kindergarten, Singaraja, Bali-Indonesia.

This study was a descriptive qualitative classroom research conducted at Aura Sukma Insani Bilingual Kindergarten. The participants were EFL teachers and children of two ECE classrooms. There were 40 children in both classrooms observed unobtrusively. Data were collected through unobtrusive observation during the EFL learning interactions.

The data collection processes took several steps, they were, lesson plans implementation by teachers, unobtrusive observation of lesson implementations by observer, recordings teachers' and children's speech acts and communication strategies, and data processing in table formats. The obtained data were analyzed qualitatively. The recorded students' and teachers' speech acts were totaled 360.

\section{Result and Discussion}

The first research finding is concerned with the speech act types and sub-types. After data analysis, the speech act types and their corresponding sub-types are shown in the following table. 
Table 1. Distribution of Speech Act Types and Sub-Types

\begin{tabular}{|c|c|c|c|c|c|c|}
\hline No & $\begin{array}{c}\text { Speech Act } \\
\text { Types }\end{array}$ & $\begin{array}{l}\text { Speech Act } \\
\text { Sub-Types }\end{array}$ & $\begin{array}{c}\text { Teachers } \\
\text { (f) }\end{array}$ & $\begin{array}{c}\text { Children } \\
\text { (f) }\end{array}$ & $\begin{array}{c}\text { Total } \\
\text { (f) }\end{array}$ & $\begin{array}{c}\text { Percent } \\
(\%)\end{array}$ \\
\hline \multirow{6}{*}{1} & \multirow{5}{*}{ Directive } & a. Ordering & 50 & 7 & 57 & 15.8 \\
\hline & & b. Requesting & 116 & 0 & 116 & 32.2 \\
\hline & & c. Telling & 64 & 96 & 160 & 44.4 \\
\hline & & d. Advising & 2 & 0 & 2 & 0.5 \\
\hline & & e. Praying & 0 & 1 & 1 & 0.3 \\
\hline & \multirow{4}{*}{ Expressive } & b-Total & 232 & 104 & 336 & 93.3 \\
\hline \multirow{4}{*}{2} & & a. Thanking & 5 & 1 & 6 & 1.7 \\
\hline & & b. Welcoming & 2 & 2 & 4 & 1.1 \\
\hline & & c. Complimenting & 8 & 0 & 8 & 2.2 \\
\hline & \multicolumn{2}{|c|}{ Sub-Total } & 15 & 3 & 18 & 5 \\
\hline \multirow[t]{2}{*}{3} & Declarative & a. Confirming & 1 & 0 & 1 & 0.3 \\
\hline & \multicolumn{2}{|c|}{ Sub-Total } & 1 & $\mathbf{0}$ & 1 & 0.3 \\
\hline 4 & Assertive & a. Explaining & 5 & 0 & 5 & 1.4 \\
\hline \multicolumn{3}{|c|}{ Sub-Total } & 5 & $\mathbf{0}$ & 5 & 1.4 \\
\hline \multicolumn{3}{|c|}{ Grand Total } & 253 & 107 & 360 & 100 \\
\hline
\end{tabular}

Table 1 above shows the grand total of speech act types and sub-types produced during classroom interactions which totaled 360. The speech acts expressed during classroom interactions consisted of four types, namely directive, expressive, declarative, and assertive acts. Directive acts were the most frequently used (93.3\%), followed by expressive acts (5\%), assertive acts (1.4\%), and declarative acts $(0.3 \%)$. The telling speech acts dominated in the verbal interactions (44.4\%) followed by request speech acts (32.2\%).

The teachers were more dominant in producing the speech acts than the children. The teachers produced232 directive acts (64.44\%) but the children produced 104 directive speech acts (28.89\%); 15 expressive acts $(4.17 \%)$ but 3 expressive acts $(0.83 \%) ; 1$ declarative speech act $(0.28 \%)$ but none expressive acts (0\%); and 5 assertive acts $(1.39 \%)$ but none of assertive acts $(0 \%)$ respectively. These findings conclude that EFL interaction pattern was more of a teacher-centered than a student-centered.

When data were focused on speech act sub-types, the results clearly show the following phenomena. In directive act sub-types, the EFL teachers deployed 116 request strategies (32.22\%) but the students deployed none (0\%); 64 telling strategies (17.78\%) deployed by teachers but 96 telling strategies $(26.67 \%)$ deployed by the students; 50 ordering strategies $(13.89 \%)$ deployed by the teachers but $7(1.94 \%)$ deployed by the students; 2advising strategies $(0.56 \%)$ deployed by the teachers but none $(0 \%)$ by the students; none praying strategy deployed by the teachers but $1(0.28 \%)$ deployed praying strategy by the students. In expressive act sub-types, the EFL teachers deployed 5thanking strategies $(1.39 \%)$ but the students deployed $1(2.28 \%)$ thanking strategy; 2 thanking strategies $(0.56 \%)$ deployed by teachers but 2 thanking strategies $(0.56 \%)$ deployed by the students; 8thanking strategies $(2.22 \%)$ deployed by the teachers but none $(0 \%)$ deployed by the students. In declarative act sub-types, the EFL teachers deployed 1confirming strategy (2.28\%) but the students deployed none (0\%). And, in assertive act sub-types, the EFL teachers deployed 1 explaining strategy $(2.28 \%)$ but the students deployed none $(0 \%)$.

The second research finding is concerned with communication strategy. Table 2 shows the distribution of the teachers' and children's communication strategies delivered during classroom interactions at Aura Sukma Insani Bilingual Kindergarten, Singaraja, Bali-Indonesia.

Table 2. Distribution of Communication Strategies

\begin{tabular}{|c|c|c|c|c|c|c|c|}
\hline No & $\begin{array}{l}\text { Communication } \\
\text { Strategies }\end{array}$ & & $\begin{array}{c}\text { Communication } \\
\text { Sub-Strategies }\end{array}$ & $\begin{array}{l}\text { Teachers } \\
\text { (f) }\end{array}$ & $\begin{array}{l}\text { Children } \\
\text { (f) }\end{array}$ & $\begin{array}{c}\text { Total } \\
\text { (f) }\end{array}$ & $\begin{array}{c}\text { Percent } \\
(\%)\end{array}$ \\
\hline \multirow[t]{3}{*}{1} & \multirow[t]{3}{*}{$\begin{array}{l}\text { Compensatory } \\
\text { strategies }\end{array}$} & 1) & $\begin{array}{l}\text { Intra-actional } \\
\text { strategies } \\
\text { Use of non-linguistic } \\
\text { means }\end{array}$ & 14 & 6 & 20 & 5.56 \\
\hline & & (2) & Code-Switching & 280 & 0 & 280 & 77.78 \\
\hline & & (3) & Self-repair & 14 & 0 & 14 & 3.89 \\
\hline
\end{tabular}




\begin{tabular}{llcccc}
\hline No $\begin{array}{c}\text { Communication } \\
\text { Strategies }\end{array}$ & \multicolumn{1}{c}{$\begin{array}{c}\text { Communication } \\
\text { Sub-Strategies }\end{array}$} & $\begin{array}{c}\text { Teachers } \\
\text { (f) }\end{array}$ & $\begin{array}{c}\text { Children } \\
\text { (f) }\end{array}$ & $\begin{array}{c}\text { Total } \\
\text { (f) }\end{array}$ & $\begin{array}{c}\text { Percent } \\
\text { (\%) }\end{array}$ \\
\hline & $\begin{array}{l}\text { (4) Use of all-purpose } \\
\text { words }\end{array}$ & 14 & 0 & 14 & 3.89 \\
& $\begin{array}{l}\text { (5) Use of filters/ } \\
\text { hesitation devices }\end{array}$ & 0 & 8 & 8 & 2.22 \\
& $\begin{array}{l}\text { (6) Literal Translation } \\
\text { Sub-Total }\end{array}$ & 0 & 12 & 12 & 3.33 \\
2) Inter-actional & $\mathbf{3 2 2}$ & $\mathbf{2 4}$ & $\mathbf{3 4 6}$ & $\mathbf{9 6 . 1 1}$ \\
& $\begin{array}{l}\text { strategies } \\
\text { (1) Asking for repetition }\end{array}$ & 14 & 0 & 14 & 3.89 \\
\hline Sub-Total & & $\mathbf{1 4}$ & $\mathbf{0}$ & $\mathbf{1 4}$ & $\mathbf{3 . 8 9}$ \\
\hline Grand Total & & $\mathbf{3 3 6}$ & $\mathbf{2 4}$ & $\mathbf{3 6 0}$ & $\mathbf{1 0 0}$ \\
\hline
\end{tabular}

Table 2 shows the phenomena in deploying communication strategies. There were 360 communication strategies deployed by both the teachers and children. The directive acts, particularly the telling and request sub-speech acts, were delivered using compensatory strategies (96.11\%). The EFL teachers used 280 code-switching strategy $(77.78 \%)$ while the children used none $(0 \%)$ codes-witching strategy; 14 non-linguistic forms strategy (3.89\%) were used by the teachers while6self-repairs strategy $(1.67 \%)$ were used by the children;14 all-purpose words strategy $(3.89 \%)$ were used by the teachers while none was used by the children;14 asking for repetitions strategy (3.89\%) were used by the teachers while none $(0 \%)$ was used by the children; filters/hesitation devices strategy was none $(0 \%)$ used by the teachers while $8(2.22 \%)$ were used by the children; none $(0 \%)$ literal translation strategy was used by the teachers while $12(3.33 \%)$ were used by the children. In general, the teachers more frequently used different strategies (93.33\%) than the children (6.67\%) in early childhood education at Aura Sukma Insani Bilingual Kindergarten.

The telling and request sub-speech acts functioned as an inquiry on a date in the calendar, for examples "What day is it today? What is the month? What is the year?" In order to check the children's understanding, the teacher asked the children to switch English into Indonesian, for examples, "What is Tuesday in Bahasa?". The children responded with a code switch strategy "Selasa". Telling acts were produced on classroom stuffs in the classroom and the dates, months, and year. The teachers used request acts to ask questions, to do things, or to take things in the classroom.

Ordering acts were often used by the teachers, for examples, "Praja, Kenzi, Kimi, Dian, and Satya take one thing. Put it back on the carpet and back to your position. Hurry up! Danika, stand up and come here! 'Ordering acts were produced to ask children to mention the stuffs' names of things in the classroom. Each child had to take one thing and mentioned the name. After all the children mention the names, they were asked to put them back on the carpet. The meanings were made clear to children through direct orders.

Suggestion acts were often heard during classroom interactions. For examples, "Before we start our lesson, it is better for us to pray to God". It is an act used as a means to build children's religious character. Children prayed in Indonesian, "Ya Tuhanku lindungilah mereka yang kucintai ayah, ibu, kakak, adik dan diriku sendiri, Amin"-- Oh Lord, protect my beloved father, mother, older brothers, younger brothers, younger sisters, and myself. Ameen. Welcoming acts were often used to harangue others respectfully, for examples, "Good morning students"; "Good morning Mr. Billy"; "How are you today?"; "I am very well". The teachers produced welcoming acts when they entered the classroom and the children responded accordingly. Through these verbal interactions children learn to respect other people regardless of their race, religion, or castes.

Thanking and complimenting speech acts were often used during learning interactions. Thanking acts were produced when children complied to the teacher's order. Complimenting acts were used when children responded the teacher's set of stimuli. Here are examples whereby thanking and complimenting acts used by the teacher and children.

Teacher: "This one? Big or small?"

Child: "Big"

Teacher: "Big what? What is this?"

Child: "Big ball"

Teacher: "Ok excellent. Put it back on the carpet. Thank you."

Explaining acts were also used during classroom communications by the interlocutors. Explaining acts were used to explain rules of the game and what should children do during the game. The teacher 
produced explaining acts to give clear instruction about the game. Here are examples whereby explaining acts used.

"Next, every corner here has one thing, then I will ask you stand up in the middle. After that I will turn on the music, when the music is on, you can dance you can go around. After the music is off or paused, I will ask you to go. Go means you find one of these corner and I will ask you a question."

Confirming acts were produced in verbal interactions between teachers and children in early childhood education. Confirming acts were produced to compliment on children's completed homework in due time.

\author{
Teacher: "Ok, before we sing a song, I want to ask you something. Who \\ make your homework? Yourself, your mama or your papa?" \\ Children: "Myself" \\ Teacher: "Is that right?"
}

Communication strategies were also recorded during learning interactions in early childhood education. Code-switching strategies were most frequently used by teachers. Teachers often alternated two languages in the same speech to children. Teachers used code-switching when they told, requested, and ordered children verbally. Code-switching was used in order to help children get the meanings of the information, question, and order given. Here are the examples of code-switches.

Teacher: "Gusti ayu, what do you want to be?"

Student: "A teacher"

Teacher: "Listen, ya! Nanti akan miss Tanya, yang tidak listen akan miss

kasi stample, berarti kalian tidak listen. Yurina, later on what do you

want to be?"

Student: "Doctor"

Teacher: "What Yurina wants to be?"

Students: "Doctor"

Teacher: "Doctor, very good. Nanti kalau Miss Lina sakit periksa ke Yurinaya?"

The first example was produced when the teacher ordered the children to listen to their friend's answer about what she wanted to be. The teacher emphasized those who not listen would be gave a stamp. While the second example was produced when the teacher asked children what they wanted to be in the future. Use of fillers/hesitation devices is known as a 'communication maintenance strategy'. From the first example, the teacher used fillers/hesitation devices. For examples,

Teacher: "Before that please aaa..Agas take me one chair, please."

Teacher: "Ananta, what do you want to be?"

Student: "Aaa..Arsitek"

Use of non-linguistic means were observed during classroom communication between teachers and children in early childhood education.

Teacher: "Alecia, what do you want to be? Do you want to be a makeup

artist like your mama?"

Student: (the student responds the question given by nodding her head)

When the teacher asked the child "Alecia, what do you want to be? Do you want to be a makeup artist like your mama?". The child responded by nodding her head. That meant the child wanted to be a makeup artist like her mother. She preferred to nod her head rather than answer the question with a 'yes'. Nonlinguistic mean was used when the child preferred to use a non-verbal act.

All-purpose words were used to tell children what they like by tweaking the other. The teacher uttered 'what we call it' to expand an empty lexical item to the context where certain words were lacking. For example,

Teacher: "One of you like to, what we call it". This one" (the teacher tweaks her hand)

Literal translations were other communication strategies used. Literal translation was used when the teacher translated literally a lexical item or structure from L1 to L2 to help the children understand the meaning of English utterances. For examples, literal translations were used by translating the literal meanings of 'salty' and 'sweet' in Indonesian. Children would recognize the translations of 'asin' for salty and 'manis for sweet.'

Self-repair strategy was self-initiated correction used by the teacher in a speech. It was used by the teacher to ask children to mention two names. For example, the teacher asked 'please tell me' but then he 
corrected his speech by uttering 'please mention'. It was used to make children understand the instruction that given.

Teacher: "Ok, my question, please tell me, please mention two names of thing in the classroom"

Asking for repetition strategy by uttering the word "sorry?". It was produced when the child's answer was not heard clearly. The teacher unconsciously asked the child to repeat the answer by uttering "sorry?". For example,

Teacher: "Ok, I take crayon. Next, one more thing, Indra."

Child: "Pencil"

Teacher: "Sorry?"

\section{Discussion}

The speech acts produced in early childhood education's communication were totaled 360 . The teachers were more dominant in producing speech acts than the children. The teachers produced $64.44 \%$ directive acts but the children produced $28.89 \%$ directive speech acts; $4.17 \%$ expressive acts produced by the teachers but $0.83 \%$ expressive acts by the children; $0.28 \%$ declarative speech acts produced by the teachers but none expressive acts produced by the children; and $1.39 \%$ assertive acts produced by the teachers but none of assertive acts produced by the children respectively. These findings conclude that EFL interaction pattern was more of a teacher-centered than a student-centered. These implied that teachers showed a more dominant position in the classroom communication.

The most frequent speech act used by the teacher and the children was directive acts with the frequency 93.3\%. The teachers produced more directive act rather than the children. Which the teachers produced directive act 232 times while the children only 104 times. (Merdana et al., 2013) from their research also found that the teachers mostly produced directives type of speech acts, while the students mostly response to the teachers' directive. Directive act created in types of requested, requirement, and advisory. It used by the teacher to control, organization, and motivated the students. According to (Searle, 1979), directive is the category of speech which directs the interlocutors to do something in order to fulfill the speaker's want or wish which expressed in them. In this study, directive act was found to be produced in every learning activity of the learning situations observed. The teachers were more active in using directive act than the children. It was supported by (Yulfi, 2017) that stated the most dominant type of speech acts on classroom communication was directive and the teacher more often used it to give command, suggestion, and request. In the present study, the teachers asked the children to do the intended meaning, such as asked the children to answer the questions, followed the instructions, and did the task that given by the teachers.

The most frequent sub-type used of directive act was telling act with the frequency $44.4 \%$. The children produced more telling act rather than the teachers. They produced 96 times telling act while the teachers produced 64 times. In this study, it showed that the teachers and the children produced telling act in every learning activity of the teaching and learning processes. According to (Trosborg, 1995), tell a hearer to do something is to direct him in a manner (or mode) which does not give him the option of refusal. It is more detail and complex than just stating something or giving information only. It can make someone understand about something easier. For example from the result of this study, "I will take some picture of this, just to remind you do you still remember of this or not." that produce by the teacher in main-activity. The teacher asked the children to mention the occupations after the teacher showed the pictures. In this situation, the teacher told the children that she would take some pictures and make sure if the children still remember the occupations that had been discussed in the previous meeting. The teacher produced telling act to make the children understand the information or instruction that given. While the children produced telling act to response toward the teacher's requesting act. When producing telling act, the teachers and children use some communication strategies such as code-switching, use of filters/ hesitation devices, literal translation, use of non-linguistic means, use of all-purpose words, and asking for repetition.

The communication strategies used in early childhood education are numerous, namely codeswitching, non-linguistic means all-purpose words, self-repair, asking for repetition, and literal translation strategies. The current research finding on communication strategy partially supported (Oktaviani \& Misgiyati, 2018) study. They concluded that communication strategies used by the English teachers were code switching, intralingua, IL based strategies, non-linguistics, cooperative, and formal reduction.

The most frequent strategy used by the teacher and the children was the code-switching with the frequency 77.78\%. It used only by the teachers. A research conducted by (Suarini et al., 2019) found that code-switching was the most frequent communication strategies that used by the teacher of Elementary 
Level at Bali Children Foundation. Besides, (Oktaviani \& Misgiyati, 2018) that conducted their study to find out communication strategies used by the Primary teachers at Palm Kids Elementary School of Lubuklinggau also found code-switching as the most frequent strategies that used. During the observations, the teacher used to switch two languages between English and Bahasa Indonesia. The teachers used code-switching to make the children more able to increase vocabulary mastery. The teachers used it when they wanted to explain the meaning of what they said and hoped the students understood the material.

Code switching is strategy where the speaker alternates two codes in the same speech toward the interlocutors who have the similar languages (Mujiono et al., 2013). On the observation, this strategy happened in a situation where the teacher alternated two languages (L1 and target language) in the same speech toward the interlocutors who have the similar languages. For example, "Before we start, I want to invite you to sing a song in English. No topi saya bundar, no bintang kecil, no pelangi-pelangi, no pamanku no, in English.". Based on the observation, it was found that the teacher used code-switching in prelearning activity when she invited the children to sing a song in English. The teacher mentioned some songs in Bahasa Indonesia such as topi saya bundar, bintang kecil, pelangi-pelangi, and pamanku. She tried to make the children understand that those songs were in Bahasa Indonesia, not in English whereas she asked them to sing a song in English. In the learning situations, the teachers used this strategy frequently when they tried to tell, request, and order something.

\section{Conclusion}

The speech acts expressed during classroom interactions consisted of four types, namely directive, expressive, declarative, and assertive acts. All speech acts functioned as verbal means for requesting, telling, ordering, advising, thanking, confirming, and explaining strategies. The communication strategies recorded during learning interactions are code-switching, use of non-linguistic means, all-purpose words, literal translations, self-repair, and asking for repetition strategies.

\section{References}

Al-Gharaibeh, S., \& Al-Jamal, D. A. (2016). Communication Strategies for Teachers and their Student in an EFL Setting. International Journal of Bilingual \& Multilingual Teachers of English, 4(1), 33-44. http://www.researchgate.net/publication/306323804_Communication_Strategies_for_Teachers_a nd_their_Students_in_an_EFL_Setting.

Austin, J. L. (1962). How To Do Things With Words. London: Oxford University Press.

Azarnoosh, M. (2014). Communicating in a Second Language: A Matter of Teaching Communication Strategies.

Basra, S. M., \&Thoyyibah, L. (2017). A SPEECH ACT ANALYSIS OF TEACHER TALK IN AN EFL CLASSROOM. International Journal of 73. https://doi.org/10.17509/ije.v10i1.6848

Bayat, N. (2013). A study on the use of speech acts. Procedia - Social and Behavioral Sciences, 70, 213-221. Retrivied from: https://doi.org/10.1016/j.sbspro.2013.01.057 on january $2^{\text {th }}, 2020$.

Bijani, H., \& Sedaghat, A. (2016). The application of Communication Strategies by Students with Different Levels of Communication Apprehension in EFL Context. Theory and Practice in Language Studies, $6(2)$,

366-371. http://www.academypublication.com/ojs/index.php/tpls/article/download/tpls0602366371/602

Brown, H. D. (2007). Principles of Language Learning and Teaching (5 $5^{\text {th }}$ ed.). White Plains, NY: Pearson Education.

Corder, S. (1983). Strategies of Communication. In C. Faerch and G. Kasper, (Eds.) Strategies in Interlanguage Communication. London: Longman, 15-19.

Dörnyei, Z \& Scott, M. (1997). Communication Strategies in a Second Language Definitions and Taxonomies. Language Learning, 47(1), 173-209. https://doi.org/10.1111/0023-8333.51997005

Fatima Sultan Shaikh. "Effective Methods of Teaching English as a Second Language in the Classroom", International Journal of Science and Research (IJSR), https://www.ijsr.net/search_index_results_paperid.php?id=SUB151296, Volume 4 Issue 2, February 2015, 979 - 984

Faerch, C. \& Kasper, G. (1983). Plans and strategies in foreign language communication. In C. Faerch and G. Kasper (Eds.), Strategies in interlanguage communication (pp. 20-60). London: Longman.

Gooden, C. \& Kearrns, J. (2013). The Importance of Communication Skills in Young Children. Human 
Development Institue. Unversity of Kentucky.

Hunter, T., \& Walsh, G. (2013). From policy to practice?: the reality of play in primary school classes in Northern Ireland. International Journal of Early Years Education, 22(1), 1936. doi:10.1080/09669760.2013.830561

JarmilaBubikova-Moan, Hanne NæssHjetland \& Sabine Wollscheid (2019) ECE teachers' views on playbased learning: a systematic review, European Early Childhood Education Research Journal, 27:6, 776-800, DOI: 10.1080/1350293X.2019.1678717

Jonsson, A. \& Williams, P. (2013). Communication with young children in preschool: the complex matter of a child perspective, Early Child Development and Care, 183:5, 589-604, DOI: 10.1080/03004430.2012.678488

Mariani, L., Communication strategies: Learning and teaching how to mangage oral interaction, NA: Learning Path-Tante Vie Per Imparare, 2010.

Martínez-Adrián, M., Gallardo-del-Puerto, F., \& Basterrechea, M. (2017). On self-reported use of communication strategies by CLIL learners in primary education. Language Teaching Research, 136216881772205. doi:10.1177/1362168817722054

Merdana, Seken, K., \& Putra, N. A. (2013). An Analysis of Speech Acts Produced by Elementary School Teachers and Students to Facilitate Teaching and Learning at SDN 10 Peringgasela East Lombok. eJournal Program Pascasarjana Universitas Pendidikan Ganesha. https://www.neliti.com/id/publications/118108/an-analysis-of-speech-acts-pruduced-byelementary-schoo;-teachers-and-students-t.

Mujiono, Poedjosoedarmo, S., Subroto, E., \& Wiratno, T. (2013). Code-switching in English as Foreign Language Instruction Practiced by English Lecturers at Universities. International Journal of Linguistics, 5(2), 46-64. Retrieved from: http://www/macrothink.org/journal/index.php/ijl/article/download/3561/pdf on December 12th, 2019.

Nakatani, Y. (2010). Identifying Strategies that Facilitate EFL Learners' Oral Communication: A Classroom Study Using Multiple Data Collection Procedures. The Modern Language Journal, 94, 116-136. https://onlnelibrary.wiley.com/doi/full/10.1111/j.1540-4781.2009.00987.x.

Nassaji, H. (2015). Qualitative and Descriptive Research: Data Type Versus Data Analysis. Language Teaching Research, 19(2) 129-132. DOI: 10.177/13626885572747

Norrick, N. R. (1978). Expressive Illucotionary acts. Journal of Pragmatics, 277-291. Retrieved December 15, 2013, from https://www.scienticedirect.com/science/artcle/abs/pii/037821667890005X

Nurani, N. P. (2015). A pragmatic analysis of classroom speech acts in the English teaching and learning process at SMA N 1 Purworejo (A Case Study). (Unpublished Thesis). Yogyakarta State University, Indonesia.

Oktaviani, A., \& Misgiyati, D. (2018). Communication Strategies Used by the Primary Teachers in EFL Classroom. Linguistic, English Education and Art (LEEA) Journal,2(1), 1-18. https://doi.org/https://doi.org/10.31539/leea.v2i1.386.

Palupi, M. D. (2008). Communication Strategies Used by EFL Young Learners of Sixth Graders Elementary School At Cita Hati Surabaya. Unpublished thesis. Surabaya: Petra Chirstian University.

Ryckebusch, C., \& Marcos, H. (2004). Speech acts, social context and parent-toddler play between the ages of 1;5 and 2;3. Journal of Pragmatics, 36(5), 883-897. doi:10.1016/j.pragma.2003.10.019

Searle, J. R. (1979). Expression and Meaning: Studies in the Theory of Speech Acts. Cambridge: Cambridge University Press.

Suarini1, N. W., Seken, I. K., \& Padmadewi, N. N. (2019). The Use of Communication Strategies by The Teacher as aTechnique of Teaching to Help Students Learn to Communicate in English on Elementary Level in Bali Children Foundation. Jurnal Pendidikan Bahasa Inggris Undiksh. 7(1), 4858. http://dx.doi.org/10.23887/jpbi.v7i1.20607

Syahrial, A. (2013). Types of Communication Strategies Used by Young Learners in Bethany School Salatiga. The $7^{\text {th }}$ International Seminar. http://ris.uksw.edu/download/makalah/kode/M01188.

Trosborg, A. (1995). Interlanguage Pragmatics: Request, Complaints, and Apologies. Berlin: Mouton de Gruyter.

Velentzas, J. O. H. N. \& Broni, G. (2014). Communication cycle: Definition, process, models and examples. Recent advances in financial planning and product development, 117-131. 